\title{
Exploratory studies on the crossbred duck farming from two upazillas under Noakhali district in Bangladesh
}

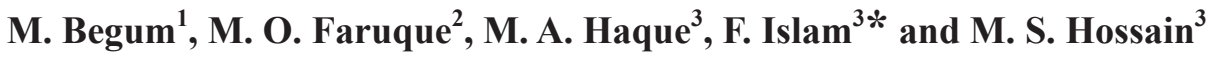 \\ ${ }^{1}$ Department of Poultry Science, Bangladesh Agricultural University, Mymensingh \\ ${ }^{2}$ Conservation and Improvement of native Sheep through Community and Commercial Farming Project, Bangladesh Livestock \\ Research Institute, Savar, Dhaka \\ ${ }^{3}$ Department of Animal Breeding and Genetics, Bangladesh Agricultural University, Mymensingh
}

\begin{abstract}
A total number of 50 crossbred duck (indigenous $\times$ exotic crossbred) farmers from 15 villages under Noakhali district in Bangladesh were selected from April to May 2017 to explore information about crossbred duck farming. Data were collected by door to door visit using a pre-structured questionnaire and collected data were analyzed using SAS software. Fifty percent of the respondents used commercial ready feed to supplement the feed and $90.00 \%$ farmers maintained own water reservoirs to swim and scavenge of their crossbred duck with prepared mixed feed. In $90.00 \%$ farms, housewives took care of the crossbred duck and spent the money earned from farming. Most of the farmers vaccinated (90.00\%) and de-wormed (94.00\%) their crossbred ducks. Natural uncontrolled flock mating system was exercised $(100.00 \%)$ during study period. About $62.00 \%$ farmers selected higher egg producer and $74.00 \%$ farmers used to hatch crossbred duck eggs to produce day old ducklings. Khaki color crossbred duck (166 \pm 1.54 pcs) laid the highest number of eggs and this was followed by mixed $(156 \pm 0.88 \mathrm{pcs})$ and white plumage colored duck $(151 \pm 1.39 \mathrm{pcs})$. But, Khaki color crossbred ducks $(2.06 \pm 0.02 \mathrm{~kg})$ were heavier than those of white $(1.72 \pm 0.04 \mathrm{~kg})$ and mixed plumage colored $(1.68 \pm 0.05 \mathrm{~kg})$ ones. It is suggested that crossbred Khaki color ducks were better performer in the village women driven duck farms but farmers were not aware of inbreeding problems.
\end{abstract}

Keywords: Crossbred duck; Farming; Village; Bangladesh

\section{Introduction}

Ducks are playing vital role in supplying complete protein to the villagers of Bangladesh. Next to chickens, ducks are main poultry species which are treated as standby money generator of village women in the coastal and haor area of Bangladesh. Now a day beside chicken farming small and medium scale duck farming are getting priority and popularity. According to BER (2012), duck population in Bangladesh was 45.12 million and available duck varieties and breeds are Non-descript indigenous, Sylhet Mete, Nageswari, Muscovy, Khaki Cambell, Indian Runner, Jinding, Cherry Valley and crossbreed of indigenous and exotic duck (Banglapedia, 2015). Per capita availability of milk, meat (livestock and poultry all together) and eggs, were $91.03 \mathrm{ml} / \mathrm{head} /$ day, 65.03 $\mathrm{gm} / \mathrm{head} /$ day and $50.00 \mathrm{nos} / \mathrm{head} /$ year but, FAO recommended $250 \mathrm{ml}$ milk/head/day, $120 \mathrm{gm}$ meat /head/day and 104.00 nos of eggs/head/year, respectively (MoFL, 2013). Using locally available foodstuffs to feed
Khaki Campbell duck had no adverse effect on egg productivity (Nho and Tieu, 1997). Marshy lands were in plenty $(67 \%)$ to the surroundings of the duck habitats and duck rearing was mostly lead by the women (80\%) and their level of education varied from primary level (43\%) to higher secondary $(7 \%)$ levels. Some farmers provided supplementary feed $(40 \%)$ for their ducks but most of the farmers depended on the natural feed sources (60\%). Regular use of anthelmintics, supplementary feed, presence of marshy land and regular treatment helps to increase egg production and Jinding breed was found to be a good egg producer (Ghosh et al., 2012). Asian continent alone accounts for $82.6 \%$ of the total duck meat production of world duck meat and eggs are relished and consumed by the people worldwide. To increase duck egg and meat on commercial level by rural household production, intensive awareness to empower rural households for duck farming is a prerequisite (Adzitey

*Corresponding author e-mail: farukkrishibid@gmail.com 
and Adzitey, 2011). Ducks need less care and have the natural tendency of foraging on aquatic weeds, algae, green legumes, fungi, earthworms, maggots, snails, various types of insects etc. They are very hardy bird and can adapt themselves with almost all types of environmental conditions and foraging directly reduces feeding cost (Jha and Chakrabarti, 2017). Pervin et al. (2013a) reported that by supplementation of improved diets growth performance of indigenous ducklings could be improved under scavenging system of rearing. Published information in crossbred duck husbandry practices from systematic research work addressing feeding, breeding and healthcare from the villages of Noakhali district in Bangladesh is scanty. So this study was designed and conducted to explore knowledge in crossbred duck husbandry practices aiming at increased duck production.

\section{Materials and methods}

Data like number of ducks per farm, egg production, plumage color of ducks, water reservoir for swimming and scavenging, duckling collection systems, feeding system, mating system, breeding drake keeping system and healthcare system etc, were collected from a total of 50 crossbred duck farmers from 10 villages of Suborno Char and 5 villages of Hatiya upazilla (sub district) under Noakhali district in Bangladesh from April to May 2017. A pre-structured questionnaire was used to collect the data by door to door visit. At least one laying duck randomly selected in each color group to take body weight. Collected data were edited for further processing. For having frequency and means proc freq and proc means menu were used. To study the differences among means, Duncan Multiple Range Test was used and to obtain least square means the generalized linear model was followed using SAS (2006) software.

\section{Results and discussion}

\section{Crossbred duck feeding systems}

Fifty percent of the respondents reported that they used to feed their crossbred duck with commercial ready feed as supplemental feed and many $(34.00 \%)$ of them used only wheat bran for supplementation. Most of the farmers $(90.00 \%)$ maintained their own water reservoirs to swim and scavenge of their crossbred ducks. All farmers reported 8 to 10 Taka per piece of egg and most of the farmers $(90.00 \%)$ used to prepare mixed feed for their crossbred duck.

\section{Crossbred duck health care}

As majority of the housewives $(90.00 \%)$ took care of the duck, they also spent the money earned from crossbred duck farming. Most of the farmers vaccinated $(90.00 \%)$ and de-wormed $(94.00 \%)$ their crossbred ducks (Table I).

\section{Breeding systems of crossbred duck}

All farmers kept crossbred ducks and they reported that ducks usually travel about 225 feet from their farm $(86.00 \%)$. Farmers usually did not replace their drake in the flock until cull and natural uncontrolled flock mating system was exercised $(100.00 \%)$.

It is a matter of interest that many farmers $(62.00 \%)$ selected higher egg producer to form stock (Table II). Majority of the farmers $(74.00 \%)$ used to hatch crossbred duck eggs to produce day- old ducklings.

\section{Production performances of crossbred ducks}

A total 622 laying crossbred ducks were documented and a total number of 521 eggs were laid on the test day at farmer's houses (Table III).

Average laying crossbred duck number per farm, egg production per day per farm and egg production in percent were $12.44 \pm 1.34$ pc, $10.42 \pm 1.28$ pc and 83.76, respectively.

Effect of plumage color on production performances of crossbred duck

Yearly egg production per crossbred duck and body weight significantly affected by plumage color (Table IV). However number of crossbred duck per farm was not affected significantly by plumage color. Khaki color crossbred duck (166 \pm 1.54 pcs) laid the highest number of eggs and this was followed by mixed ( $156 \pm 0.88 \mathrm{pcs})$ and white plumage color ( $151 \pm 1.39$ pcs $)$.

On the other hand Khaki color crossbred duck (2.06 \pm 0.02 $\mathrm{kg})$ were heavier than those of white $(1.72 \pm 0.04 \mathrm{~kg})$ and mixed plumage colored $(1.68 \pm 0.05 \mathrm{~kg})$ ones.

\section{Crossbred duck feeding systems}

Half of the respondents used supplemental feed from commercial feed source to feed their crossbred ducks but many of them used only wheat bran as feed supplement. Similarly, Parvin et al. (2013b) reported that many farmers $(47 \%)$ used home- grown feed ingredients and half of the target farmers supplemented feeds from both commercial and home-made sources. Most of the farmers had their 
Table I. Feeding and health care practices of crossbred ducks under study period

\begin{tabular}{|c|c|c|}
\hline Parameters studied & & $\begin{array}{l}\text { Number of farmers } \\
\text { under observation }\end{array}$ \\
\hline \multirow[t]{5}{*}{ Test day feed item used } & Wheat and soybean bran & $3(6.00 \%)$ \\
\hline & No feed supply & $2(4.00 \%)$ \\
\hline & Commercial ready feed supply & $25(50.00 \%)$ \\
\hline & Rice, rice polish, wheat bran and mustard oil cake & $3(6.00 \%)$ \\
\hline & Wheat bran & $17(34.005 \%)$ \\
\hline \multirow[t]{2}{*}{ Water reservoir for swimming and scavenging } & I have of my own & $45(90.00 \%)$ \\
\hline & Do not have of my own & $5(10.00 \%)$ \\
\hline \multirow[t]{2}{*}{ Who took care of crossbred ducks by } & Wife & $45(90.00 \%)$ \\
\hline & Husband & $5(10.00 \%)$ \\
\hline Egg price & 8 to 10 Taka per egg & $50(100.00 \%)$ \\
\hline \multirow[t]{2}{*}{ Who spent money earned from crossbred duck rearing? } & Wife & $45(90.00 \%)$ \\
\hline & Husband & $5(10.00 \%)$ \\
\hline \multirow[t]{2}{*}{ Did you use to prepare mix feed for your crossbred duck? } & Yes & $45(90.00 \%)$ \\
\hline & No & $5(10.00 \%)$ \\
\hline \multirow[t]{2}{*}{ Do you know when and how many vaccines are needed for crossbred duck? } & Yes & $45(90.00 \%)$ \\
\hline & No & $5(10.00 \%)$ \\
\hline \multirow[t]{2}{*}{ Do you vaccinate your crossbred duck regularly? } & Yes & $45(90.00 \%)$ \\
\hline & No & $5(10.00 \%)$ \\
\hline \multirow[t]{2}{*}{ Do you know about de-worming program for crossbred duck? } & Yes & $50(100.00 \%)$ \\
\hline & No & 0 \\
\hline \multirow[t]{2}{*}{ Do you follow de-worming program for your crossbred duck? } & Yes & $47(94.00 \%)$ \\
\hline & No & $3(6.00 \%)$ \\
\hline
\end{tabular}

\section{Table II. Breeding practices of crossbred ducks under study period}

Parameters studied

\begin{tabular}{|c|c|c|}
\hline Duck breed & crossbred & $50(100.00 \%)$ \\
\hline \multirow[t]{2}{*}{ Duck movements } & up to 225 feet distances from home & $43(86.00 \%)$ \\
\hline & up to 300 feet distances from home & $7(14.00 \%)$ \\
\hline Mating system & Natural uncontrolled flock mating & $50(100.00 \%)$ \\
\hline \multirow[t]{2}{*}{ Using timeframe of a drake for mating purpose in a flock } & Up to 3 years of age of drake & $10(20.00 \%)$ \\
\hline & Up to cull the drake from flock & $40(80.00 \%)$ \\
\hline \multirow[t]{2}{*}{ Do you use to select higher egg producing duck for better stock formation? } & Yes & $31(62.00 \%)$ \\
\hline & No & $19(38.00 \%)$ \\
\hline \multirow[t]{2}{*}{ From where do you collect ducklings? } & Natural hatching at home & $37(74.00 \%)$ \\
\hline & Purchase outside home & $13(26.00 \%)$ \\
\hline
\end{tabular}


Table III. Total number of laying duck and egg production reported on test day at farmer's house

Parameters studied

Number of farmers under observation

Total number of laying duck documented at 50 farmers house 622

Total number of eggs counted at 50 farmers house

Egg production in percent

Total number of eggs sold at 50 farmers house

Average laying duck number documented per farmer

$12.44 \pm 1.34$

Average egg production recorded per farmer

$10.42 \pm 1.28$

Table IV. Mean \pm SE of number of laying duck, egg production per year per duck and body weight per laying duck

\begin{tabular}{lccc}
\hline Parameters studied & \multicolumn{2}{c}{ Plumage color of crossbred ducks } & \multirow{2}{*}{$\mathrm{p}$ value } \\
\cline { 2 - 4 } & Khaki & White & Mixed \\
\hline Number of laying crossbred ducks per farm & $4.70 \pm 0.58(50)$ & $4.80 \pm 0.87(50)$ & $3.48 \pm 0.34(50)$ \\
Yearly egg production per crossbred ducks & $166 \mathrm{a} \pm 1.54(50)$ & $151 \mathrm{c} \pm 1.39(50)$ & $156 \mathrm{~b} \pm 0.88(50)$ \\
Body weight per laying crossbred ducks in kg & $2.06 \mathrm{a} \pm 0.02(50)$ & $1.72 \mathrm{~b} \pm 0.04(50)$ & $1.68 \mathrm{c} \pm 0.05(50)$
\end{tabular}

Note: ${ }^{a b c}$ Means with the different superscripts differed significantly within the row $(\mathrm{p}<0.05)$. Number in the parentheses denotes the number of farms.

own water reservoirs to swim and scavenge of their crossbred duck and they used to prepare mixed feed for their crossbred ducks. An egg was sold at 8 to 10 Taka at study site. The above discussions might be suggestive that feed was supplemented from both commercial and home grown sources and water reservoirs were also important feed source of crossbred ducks.

\section{Crossbred duck health care}

Majority of the housewives took care of the crossbred duck and spent the money earned from farming. Similarly, Parvin et al. (2013b) reported, $89.50 \%$ of the duck farmers were housewives. Most of the farmers vaccinated and de-wormed their crossbred duck.

\section{Breeding systems of crossbred duck}

Farmers reported that ducks travel about 225 feet from their farm and usually did not replace their drake in the flock until cull and natural uncontrolled flock mating system was exercised. From their own interests many farmers selected higher egg producer to form stocks. Majority of the farmers used to hatch crossbred duck eggs to produce day-old ducklings. On the contrary, most of the farmers $(90 \%)$ bought day old ducklings from private hatching farms but only $10 \%$ of them bought the same from poultry research centers (Ton and Thang, 2014).

\section{Production performances of crossbred ducks}

Average laying crossbred duck numbers per farm was higher than Halder et al. (2007) who recorded majority of flocks comprised of 6-10 ducks and lower than Islam et al. (2002) who reported that $85.6 \%$ of the flocks comprised 20-50 ducks. Egg production in percent was higher than egg production in Sundargonj (68.8\% for exotic duck) and in Netrokona (47.9\% for local duck) (Khanum et al., 2005). The discussions might be suggestive that flock size was medium compared to other findings and egg production performances was better than those of the findings of some researchers at home and abroad. 
Effect of plumage color on production performances of crossbred duck

Plumage color affected yearly egg production per crossbred duck and body weight significantly but number of crossbred ducks per farm was not affected significantly. Khaki color crossbred ducks (166 \pm 1.54 pcs) laid higher number of eggs than those of mixed color, white color, scavenging desi duck (Parvin et al., 2013b) and Khaki Campbell duck reared in tribal village of Saraitoli, Ranchi, Jharkhand, India (Jha and Chakrabarti, 2017). On the other hand Khaki color crossbred ducks $(2.06 \pm 0.02 \mathrm{~kg})$ were heavier than those of white color and mixed color and average body weight of an adult duck attained 1.30 to $1.50 \mathrm{~kg}$ (Parvin et al., 2013b). The above discussions might be indicative that khaki color crossbred ducks were better egg and meat producers than those of mixed and white colours.

\section{Conclusion}

Feed was supplemented from both commercial and home grown sources and water reservoirs were also important feed source of crossbred ducks. Majority of the housewives took care of the crossbred ducks and spent the money earned from different farming systems. Farmers used natural uncontrolled flock mating systems of their crossbred duck and majority of them used to hatch crossbred duck eggs to produce dayold ducklings. Flock size was medium and Khaki colour crossbred ducks were better egg and meat producers than those of mixed and white colours.

\section{Acknowledgement}

The authors are grateful to the villagers of study area to provide the valuable information to pursue and conduct the research work.

\section{References}

Adzitey F and Adzitey SP (2011), Duck production: Has a potential to Reduce Poverty among Rural Households in Asian Communities -A review, Journal of World's Poultry Research 1: 17-10.

Banglapedia (2015), National Encyclopedia of B angladesh, http://en.banglapedia.org/ index .php? title $=$ Cattle.
BER (2012), Bangladesh Economic Review (BER), Ministry of Finance, Government of the People's Republic of Bangladesh, Dhaka, pp 92-93.

Ghosh S, Haider N and Khan MKI (2012), Status of Household's Ducks and their Associated Factors under Scavenging System in a Southern Area of Bangladesh, International Journal of Natural Sciences 2(4): 108-112.

Halder G, Ghoshal TK and Samanta G (2007), Socio-economic background of duck owners and status of duck rearing in West Bengal, Indian Research Journal Extension Education 7(2\&3): 56-59.

Islam R, Mahanta JD, Barua N and Zaman G (2002), Duck farming in North-Eastern India (Assam), World's Poultry Science Journal 58(4): 567-572.

Jha BK and Chakrabarti A (2017), Duck farming: a potential source of livelihood in tribal village, Journal of Animal Health and Production 5(2): 39-43.

Khanum J, Chwalibog A and Huque KS (2005), Study on rural duck production systems in selected areas of Bangladesh, Livestock Research for Rural Development Volume 17 Article \#113.

MoFL (2013) Department of Livestock Services, Ministry of Fisheries and Livestock (MoFL), Government of the People's Republic of Bangladesh, Dhaka.

Nho LT, Tieu HV (1997). Egg production and economic efficiency of Khaki Campbell ducks reared on locally available feedstuffs in the coastal land stretch of the Red River Delta, Livestock Research for Rural Development 9: 1.

Pervin W, Chowdhury SD, Ali MA, Khan JU and Raha SK (2013a), Growth performance of indigenous (desi) ducklings receiving diets of varying nutrient concentrations, Proc. $8^{\text {th }}$ Poultry Show and Seminar, World's Poultry Science Association, Bangladesh Branch, pp 45-50.

Pervin W, Chowdhury SD, Hasnath MR, Khan MJ, Ali MA and Raha SK (2013b), Duck production 
strategy and profile of duck farmers in the coastal areas of Bangladesh, Livestock Research for Rural Development Volume 25 Article \# 129.

SAS (2006), Statistical Analysis System, SAS Institute Inc., Cary, North Carolina, USA.
Ton VD and Thang PD (2014), Characteristics of duck production systems in Red River and Mekong River Deltas, Journal of Animal Husbandry Sciences and Technics 22(185): 65-72. 